Prepared in cooperation with the Montana Department of Transportation, Montana Department of Environmental Quality, and Montana Department of Natural Resources and Conservation

\title{
Adjusted Peak-Flow Frequency Estimates for Selected Streamflow-Gaging Stations in or near Montana Based on Data through Water Year 2011
}

Chapter D of

Montana StreamStats

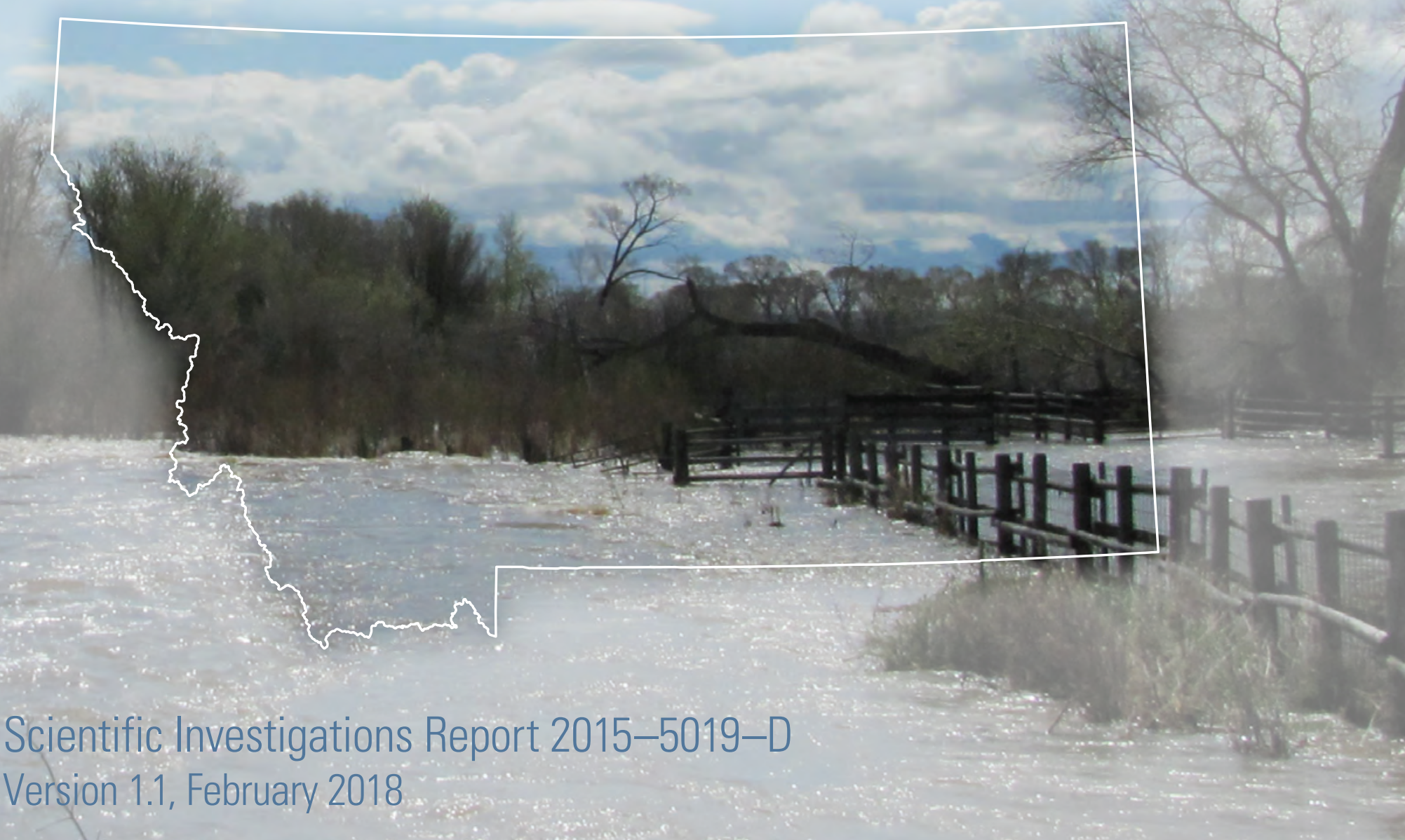

\section{U.S. Department of the Interior}

U.S. Geological Survey 
Cover photograph: Flooding at the Musselshell River near Martinsdale, Montana streamgage.

Photograph by U.S. Geological Survey personnel, May 23, 2011. 


\section{Adjusted Peak-Flow Frequency Estimates for Selected Streamflow-Gaging Stations in or near Montana Based on Data through Water Year 2011}

By Steven K. Sando, Roy Sando, Peter M. McCarthy, and DeAnn M. Dutton

Chapter D of

Montana StreamStats

Prepared in cooperation with the Montana Department of Transportation, Montana Department of Environmental Quality, and Montana Department of Natural Resources and Conservation

Scientific Investigations Report 2015-5019-D

Version 1.1, February 2018 


\title{
U.S. Department of the Interior RYAN K. ZINKE, Secretary
}

\section{U.S. Geological Survey William H. Werkheiser, Deputy Director exercising the authority of the Director}

\author{
U.S. Geological Survey, Reston, Virginia \\ First release: April 2016 \\ Revised: February 2018 (ver 1.1)
}

\begin{abstract}
For more information on the USGS - the Federal source for science about the Earth, its natural and living resources, natural hazards, and the environment-visit https://www.usgs.gov or call 1-888-ASK-USGS.

For an overview of USGS information products, including maps, imagery, and publications, visit https://store.usgs.gov.
\end{abstract}

\footnotetext{
Any use of trade, firm, or product names is for descriptive purposes only and does not imply endorsement by the U.S. Government.

Although this information product, for the most part, is in the public domain, it also may contain copyrighted materials as noted in the text. Permission to reproduce copyrighted items must be secured from the copyright owner.

Suggested citation:

Sando, S.K., Sando, Roy, McCarthy, P.M., and Dutton, D.M., 2018, Adjusted peak-flow frequency estimates for selected streamflow-gaging stations in or near Montana based on data through water year 2011 (ver. 1.1, February 2018) : U.S. Geological Survey Scientific Investigations Report 2015-5019-D, 12 p., https://doi.org/10.3133/ sir20155019D.

ISSN 2328-0328 (online)
} 


\section{Contents}

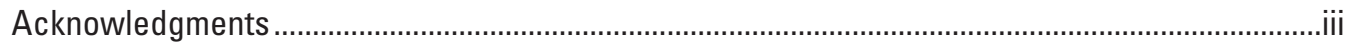

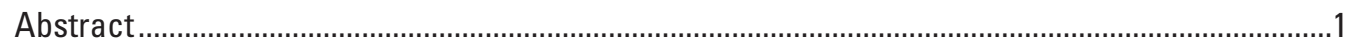

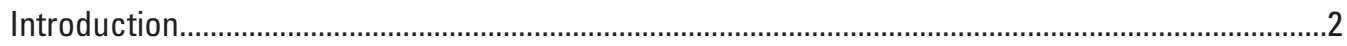

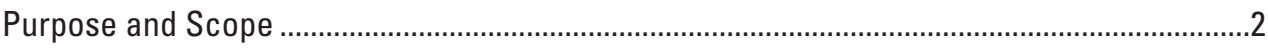

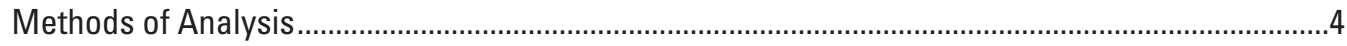

Procedures for Weighting with Regional Regression Equations.............................................

Procedures for Mixed-Station Record Extension .............................................................

Definition of Base Periods........................................................................................

Application of the Mixed-Station Maintenance of Variance Type 1 (MOVE.1)

Analysis to Synthesize Peak-Flow Data ...............................................................5

Procedures for Frequency Analysis of the Combined Recorded and Synthesized

Peak-Flow Data ..............................................................................................6

Adjusted Peak-Flow Frequency Estimates for Selected Streamflow-Gaging Stations in or

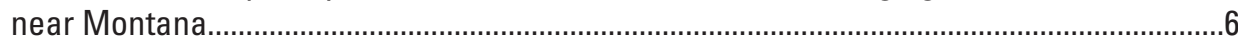

Adjusted Peak-Flow Frequency Estimates Determined by Weighting with Regional

Regression Equations ............................................................................................

Considerations for Interpreting Results for Weighting with Regional Regression Equations .......................................................................................................

Adjusted Peak-Flow Frequency Estimates Determined by Mixed-Station Record

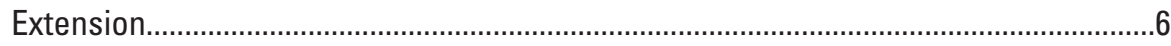

Considerations for Interpreting Mixed-Station Record Extension Results.......................7

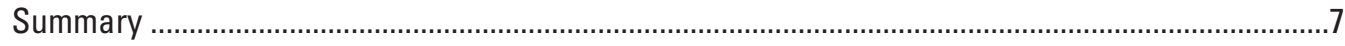

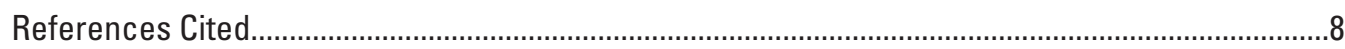

Appendix 1. Information on Selected Streamflow-Gaging Stations, Peak-Flow Frequency

Adjustment Methods, And Adjusted Peak-Flow Frequency Estimates...............................12

\section{Figures}

1. Map showing locations of selected streamflow-gaging stations in or near Montana

\section{Appendix Tables}

1-1. Information on selected streamflow-gaging stations in or near Montana for which at-site peak-flow frequencies were adjusted..

1-2. Peak-flow frequency estimates for selected streamflow-gaging stations in or near Montana that were adjusted by weighting with regional regression equations.............12

1-3. Documentation regarding the application of the mixed-station maintenance of variance type I (MOVE.1) record extension procedure for selected streamflowgaging stations in or near Montana 
1-4. Documentation regarding analytical procedures for peak-flow frequency analyses on combined recorded and synthesized peak-flow data for selected streamflowgaging stations

1-5. Peak-flow frequency estimates for selected streamflow-gaging stations in or near Montana that were adjusted by mixed-station record extension

\section{Conversion Factors}

Inch/Pound to International System of Units

\begin{tabular}{lcl}
\hline \multicolumn{1}{c}{ Multiply } & By & \multicolumn{1}{c}{ To obtain } \\
\hline & Area & \\
\hline square mile $\left(\mathrm{mi}^{2}\right)$ & 259.0 & hectare $(\mathrm{ha})$ \\
square mile $\left(\mathrm{mi}^{2}\right)$ & 2.590 & square kilometer $\left(\mathrm{km}^{2}\right)$ \\
\hline & Flow rate & \\
\hline cubic foot per second $\left(\mathrm{ft}^{3} / \mathrm{s}\right)$ & 0.02832 & cubic meter per second $\left(\mathrm{m}^{3} / \mathrm{s}\right)$ \\
\hline
\end{tabular}

Temperature in degrees Celsius $\left({ }^{\circ} \mathrm{C}\right)$ may be converted to degrees Fahrenheit ( $\left.{ }^{\circ} \mathrm{F}\right)$ as follows:

$$
{ }^{\circ} \mathrm{F}=\left(1.8 \times{ }^{\circ} \mathrm{C}\right)+32 .
$$

Temperature in degrees Fahrenheit $\left({ }^{\circ} \mathrm{F}\right)$ may be converted to degrees Celsius $\left({ }^{\circ} \mathrm{C}\right)$ as follows:

$$
{ }^{\circ} \mathrm{C}=\left({ }^{\circ} \mathrm{F}-32\right) / 1.8 \text {. }
$$

\section{Datums}

Horizontal coordinate information is referenced to North American Datum of 1983 (NAD 83).

Vertical coordinate information is referenced to the North American Vertical Datum of 1988 (NAVD 88).

\section{Supplemental Information}

Water year is the 12-month period from October 1 through September 30 of the following calendar year. The water year is designated by the calendar year in which it ends. For example, water year 2010 is the period from October 1, 2009, through September 30, 2010.

\section{Abbreviations}

$\begin{array}{ll}\text { AEP } & \text { annual exceedance probability } \\ \text { MOVE.1 } & \text { maintenance of variance type I } \\ \text { RRE } & \text { regional regression equation } \\ \text { SEP } & \text { standard error of prediction } \\ \text { USGS } & \text { U.S. Geological Survey } \\ \text { WIE } & \text { Weighted Independent Estimates }\end{array}$




\section{Acknowledgments}

The authors would like to recognize the U.S. Geological Survey hydrologic technicians involved in the collection of the peak-flow data for their dedicated efforts. The authors also would like to recognize the valuable contributions to this report chapter from the insightful technical reviews by Dan Driscoll and Skip Vecchia of the U.S. Geological Survey.

Special thanks are given to Mark Goodman and Dave Hedstrom of the Montana Department of Transportation and Steve Story of the Montana Department of Natural Resources and Conservation for their support of this study. 



\title{
Adjusted Peak-Flow Frequency Estimates for Selected Streamflow-Gaging Stations in or near Montana Based on Data through Water Year 2011
}

\author{
By Steven K. Sando, Roy Sando, Peter M. McCarthy, and DeAnn M. Dutton
}

\section{Abstract}

The climatic conditions of the specific time period during which peak-flow data were collected at a given streamflowgaging station (hereinafter referred to as gaging station) can substantially affect how well the peak-flow frequency (hereinafter referred to as frequency) results represent long-term hydrologic conditions. Differences in the timing of the periods of record can result in substantial inconsistencies in frequency estimates for hydrologically similar gaging stations. Potential for inconsistency increases with decreasing peak-flow record length. The representativeness of the frequency estimates for a short-term gaging station can be adjusted by various methods including weighting the at-site results in association with frequency estimates from regional regression equations (RREs) by using the Weighted Independent Estimates (WIE) program. Also, for gaging stations that cannot be adjusted by using the WIE program because of regulation or drainage areas too large for application of RREs, frequency estimates might be improved by using record extension procedures, including a mixed-station analysis using the maintenance of variance type I (MOVE.1) procedure. The U.S. Geological Survey, in cooperation with the Montana Department of Transportation and the Montana Department of Natural Resources and Conservation, completed a study to provide adjusted frequency estimates for selected gaging stations through water year 2011.

The purpose of Chapter D of this Scientific Investigations Report is to present adjusted frequency estimates for 504 selected streamflow-gaging stations in or near Montana based on data through water year 2011. Estimates of peak-flow magnitudes for the 66.7-, 50-, 42.9-, 20-, 10-, 4-, 2-, 1-, 0.5-, and 0.2-percent annual exceedance probabilities are reported. These annual exceedance probabilities correspond to the 1.5-, 2-, 2.33-, 5-, 10-, 25-, 50-, 100-, 200-, and 500-year recurrence intervals, respectively.

The at-site frequency estimates were adjusted by weighting with frequency estimates from RREs using the WIE program for 438 selected gaging stations in Montana. These 438 selected gaging stations (1) had periods of record less than or equal to 40 years, (2) represented unregulated or minor regulation conditions, and (3) had drainage areas less than about 2,750 square miles.

The weighted-average frequency estimates obtained by weighting with RREs generally are considered to provide improved frequency estimates. In some cases, there are substantial differences among the at-site frequency estimates, the regression-equation frequency estimates, and the weightedaverage frequency estimates. In these cases, thoughtful consideration should be applied when selecting the appropriate frequency estimate. Some factors that might be considered when selecting the appropriate frequency estimate include (1) whether the specific gaging station has peak-flow characteristics that distinguish it from most other gaging stations used in developing the RREs for the hydrologic region; and (2) the length of the peak-flow record and the general climatic characteristics during the period when the peak-flow data were collected. For critical structure-design applications, a conservative approach would be to select the higher of the at-site frequency estimate and the weighted-average frequency estimate.

The mixed-station MOVE. 1 procedure generally was applied in cases where three or more gaging stations were located on the same large river and some of the gaging stations could not be adjusted using the weighted-average method because of regulation or drainage areas too large for application of RREs. The mixed-station MOVE.1 procedure was applied to 66 selected gaging stations on 19 large rivers.

The general approach for using mixed-station record extension procedures to adjust at-site frequencies involved (1) determining appropriate base periods for the gaging stations on the large rivers, (2) synthesizing peak-flow data for the gaging stations with incomplete peak-flow records during the base periods by using the mixed-station MOVE. 1 procedure, and (3) conducting frequency analysis on the combined recorded and synthesized peak-flow data for each gaging station. Frequency estimates for the combined recorded and synthesized datasets for 66 gaging stations with incomplete peak-flow records during the base periods are presented. The uncertainties in the mixed-station record extension results are difficult to directly quantify; thus, it is important to understand the intended use of the estimated frequencies based on 
analysis of the combined recorded and synthesized datasets. The estimated frequencies are considered general estimates of frequency relations among gaging stations on the same stream channel that might be expected if the gaging stations had been gaged during the same long-term base period. However, because the mixed-station record extension procedures involve secondary statistical analysis with accompanying errors, the uncertainty of the frequency estimates is larger than would be obtained by collecting systematic records for the same number of years in the base period.

\section{Introduction}

Reliable information on peak-flow characteristics at specific sites is essential for many water-resources applications including effective planning and management of water resources and flood plains, protection of lives and property in flood-prone areas, determination of actuarial flood-insurance rates, and design of highway infrastructure. Peak-flow data are readily available at sites that are monitored by U.S. Geological Survey (USGS) streamflow-gaging stations (hereinafter referred to as gaging stations) and can be downloaded through the USGS National Water Information System (U.S. Geological Survey, 2014). The gaged streamflow data can be statistically analyzed to estimate peak-flow frequencies (that is, peakflow magnitudes for the 66.7-, 50-, 42.9-, 20-, 10-, 4-, 2-, 1-, $0.5-$, and 0.2-percent annual exceedance probabilities [AEPs]). These AEPs correspond to the 1.5-, 2-, 2.33-, 5-, 10-, 25-, 50-, 100-, 200-, and 500-year recurrence intervals, respectively. Sando, McCarthy, and Dutton (2016) reported at-site peakflow frequency estimates (hereinafter usually referred to as frequency estimates, or simply as frequencies) for 725 gaging stations in Montana based on data through water year 2011; a water year is the 12-month period from October 1 through September 30 and is designated by the year in which it ends.

The USGS, in cooperation with the Montana Department of Transportation and the Montana Department of Natural Resources and Conservation, completed a study to provide adjusted frequency estimates for selected gaging stations through water year 2011. Adjustments to at-site frequency estimates can be appropriate for several reasons. The climatic conditions of the specific time period during which the data were collected at a given gaging station can substantially affect how well the frequency estimates represent long-term hydrologic conditions. Differences in the timing of the periods of record can result in substantial inconsistencies in frequency estimates for hydrologically similar gaging stations. Potential for inconsistency increases with decreasing peak-flow record length. The representativeness of the frequency estimates for a short-term gaging station can be adjusted by various methods including weighting the at-site frequency estimates in association with frequency estimates from regional regression equations (RREs) by using the Weighted Independent Estimates (WIE) program as described by Cohn and others (2012). Also, for gaging stations that cannot be adjusted by using the WIE program because of regulation or drainage areas too large for application of RREs, frequency estimates might be improved by using record extension procedures, including a mixed-station analysis using the maintenance of variance type I (MOVE.1) procedure (Alley and Burns, 1983). Application of the mixed-station MOVE. 1 procedure to peak-flow records for South Dakota is described by Sando and others (2008).

\section{Purpose and Scope}

The study described in Chapter D of this Scientific Investigations Report is part of a larger study to develop a StreamStats application for Montana, compute streamflow characteristics at streamflow-gaging stations, and develop regional regression equations to estimate streamflow characteristics at ungaged sites (as described fully in Chapters A through $\mathrm{G}$ of this Scientific Investigations Report). The purpose of Chapter $\mathrm{D}$ is to present adjusted frequency estimates for selected streamflow-gaging stations (fig. 1, table 1-1 in appendix 1 at the back of this report chapter (available at https://doi. org/10.3133/sir20155019D); map numbers assigned according to McCarthy and others [2016]) in or near Montana based on data through water year 2011. Adjustments are presented for 504 of the 725 gaging stations for which frequency estimates were reported by Sando, McCarthy, and Dutton (2016). Adjusted estimates of peak-flow magnitudes for the 66.7-, 50-, 42.9-, 20-, 10-, 4-, 2-, 1-, 0.5-, and 0.2-percent AEPs are reported. These AEPs correspond to the 1.5-, 2-, 2.33-, 5-, 10-, 25-, 50-, 100-, 200-, and 500-year recurrence intervals, respectively.

The at-site frequency estimates (reported by Sando, McCarthy, and Dutton [2016]) were adjusted by weighting with frequency estimates from RREs (reported by Sando, Roy, and others [2016]) for 438 of the selected gaging stations (fig. 1, tables 1-1 and 1-2 in appendix 1 at the back of this report chapter). For 66 of the selected gaging stations (fig. 1, appendix tables 1-1 and 1-3 in appendix 1 at the back of this report chapter, available at https://doi.org/10.3133/ sir20155019D) that are located on 19 large rivers with multiple gaging stations, the at-site frequency estimates were adjusted by using mixed-station record extension procedures. The RRE weighting and mixed-station record extension procedures are documented in this report chapter. Unadjusted at-site frequency estimates for 27 long-term streamflowgaging stations (fig. 1, tables $1-1$ and 1-3) that are located on 19 large rivers also are included to assist in assessing adjusted frequency estimates for other gaging stations located on the large rivers. 


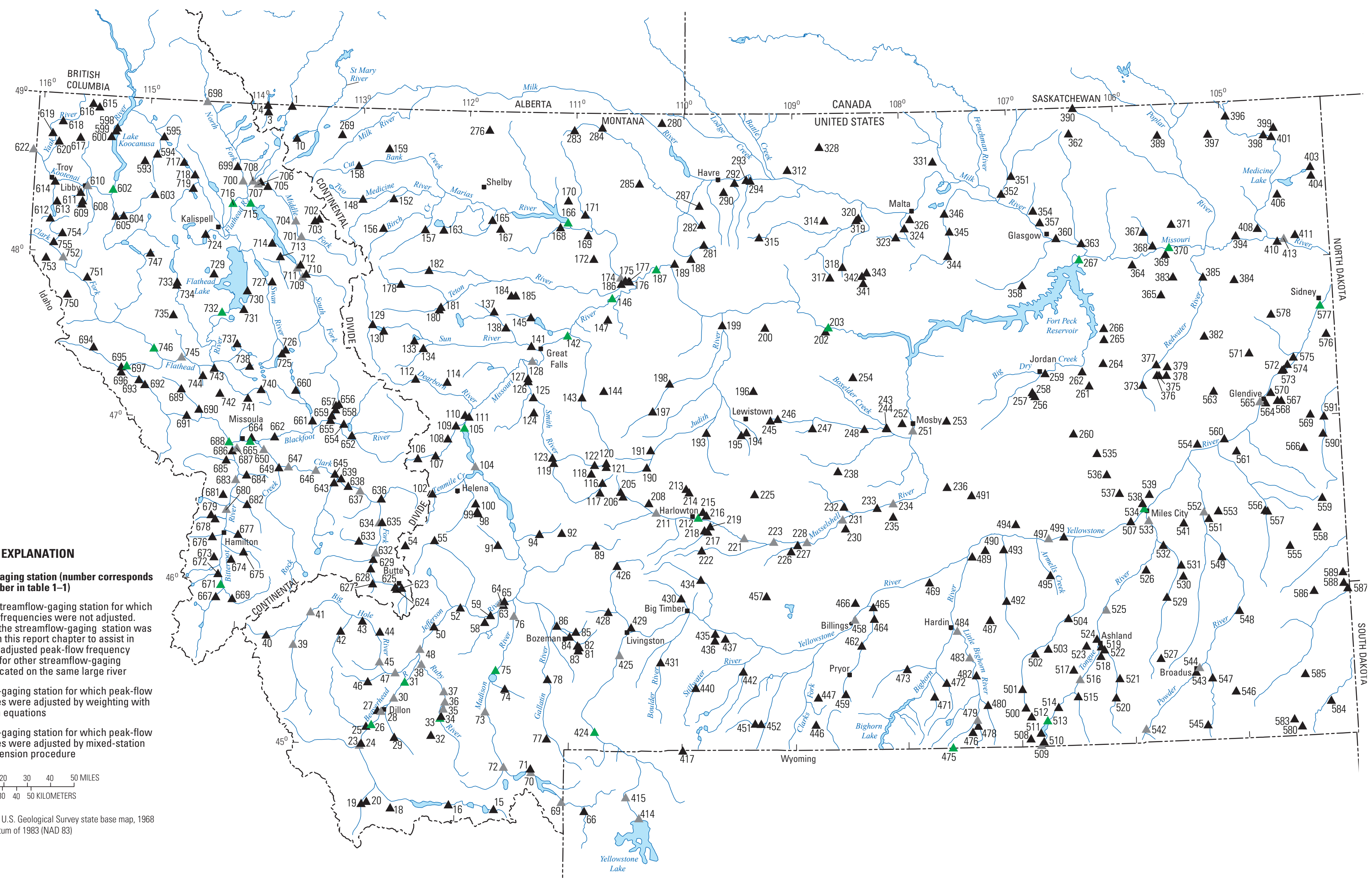

Figure 1. Locations of selected streamflow-gaging stations in or near Montana 


\section{Methods of Analysis}

At-site frequency estimates for 504 selected gaging stations (fig. 1, table 1-1) were adjusted by RRE weighting and mixed-station record extension procedures. Details on the procedures are presented herein.

\section{Procedures for Weighting with Regional Regression Equations}

Regional regression equations typically are used to estimate frequencies for ungaged sites; however, RREs also can be used to adjust at-site frequency estimates for gaging stations, which can reduce uncertainty of frequency estimates (Cohn and others, 2012). For gaging stations with characteristics that allow estimation of frequencies using RREs, the at-site frequencies can be adjusted by weighted averaging with results from RREs by using the WIE program (Cohn and others, 2012). For 438 selected gaging stations in Montana (fig. 1, tables 1-1 and 1-2), the at-site frequency estimates were adjusted by weighting with results from RREs (reported by Sando, Roy, and others [2016]). The 438 selected gaging stations (1) had periods of record less than or equal to 40 years, (2) represented unregulated or minor regulation conditions (based on criteria for determination of regulation status described by McCarthy and others [2016]), and (3) had drainage areas less than about 2,750 square miles $\left(\mathrm{mi}^{2}\right)$.

The WIE program weights the at-site frequency estimates and the RRE frequency estimates based on the meansquare errors of the two estimates. The variance of the at-site frequency estimate used in the weighting procedure was determined using the expected moments algorithm (Cohn and others, 2001). In determining the variance of the RRE frequency estimate for a given station, the at-site values of basin characteristics (explanatory variables) used in the RRE were analyzed in relation to the matrix form of the applicable generalized least squares regression equation (Tasker and Stedinger, 1989; Sando, Roy, and others, 2016) or weighted least-squares regression equation (Tasker, 1980; Sando, Roy, and others, 2016). Thus, for each gaging station, the distance of the at-site basin characteristic values from the center of the joint distribution of all values used in developing the regression equation was incorporated into the weighting process.

\section{Procedures for Mixed-Station Record Extension}

Mixed-station record extension generally was applied in cases where three or more gaging stations were located on the same large river and some of the gaging stations could not be adjusted using the weighted-average method because of regulation or drainage areas too large (greater than about 2,750 $\mathrm{mi}^{2}$ ) for application of RREs. Mixed-station record extension was applied to 66 selected gaging stations (table 1-3) on the following 19 large rivers:
1. the Beaverhead River (3 gaging stations);

2. the Ruby River (4 gaging stations);

3. the Big Hole River (4 gaging stations);

4. the Jefferson River (2 gaging stations);

5. the Madison River (5 gaging stations);

6. the Missouri River (3 gaging stations);

7. the Marias River (1 gaging station);

8. the Musselshell River (7 gaging stations);

9. the Yellowstone River (6 gaging stations);

10. the Little Bighorn River (3 gaging stations);

11. the Tongue River (4 gaging stations);

12. the Powder River (3 gaging stations);

13. the Kootenai River (2 gaging stations);

14. the Clark Fork (7 gaging stations);

15. the Bitterroot River (3 gaging stations);

16. the North Fork Flathead River (2 gaging stations);

17. the Middle Fork Flathead River (4 gaging stations);

18. the South Fork Flathead River (2 gaging stations); and

19. the Flathead River (1 gaging station).

For most of the large rivers, in addition to the gaging stations with incomplete peak-flow records during the base periods (described in the section "Definition of Base Periods"), one or more long-term gaging stations with complete datasets during the base periods were available. For all of the 19 large rivers combined, a total of 27 long-term gaging stations with complete datasets during the base periods were available.

These 27 long-term streamflow-gaging stations were included in this report chapter to assist in assessing adjusted frequency estimates for other gaging stations located on the large rivers.

The general approach for using mixed-station record extension procedures to adjust at-site frequencies involved (1) determining appropriate base periods for the gaging stations on the large rivers, (2) synthesizing peak-flow data for the gaging stations with incomplete peak-flow records during the base periods by using the mixed-station MOVE. 1 procedure, and (3) conducting frequency analysis on the combined recorded and synthesized peak-flow data for each gaging station. Details on the procedures are presented in the following sections: "Definition of Base Periods," "Application of the Mixed-Station Maintenance of Variance Type 1 (MOVE.1) Analysis to Synthesize Peak-Flow Data," and "Procedures for Frequency Analysis of the Combined Recorded and Synthesized Peak-Flow Data." 


\section{Definition of Base Periods}

For each large river (or subreach for several of the rivers), the base period typically started with the water year of earliest systematic peak-flow data collection for that river or subreach and extended to 2011. For some of the large rivers, some gaging stations had sporadic peak-flow data collected before the start of the defined base period. In those cases, peak-flow data could not be synthesized for all of the gaging stations on a given large river; thus, the base period did not include the early years of sporadic data collection.

For some of the large rivers, all of the gaging stations are affected by the same major dam or canal regulation structure (as described by McCarthy and others [2016] and Sando, McCarthy, and Dutton [2016]). In such cases, the base period was restricted to the period after the start of the regulation. For some of the large rivers, some reaches are unregulated and some reaches are regulated. In such cases, different base periods for different reaches were defined to accommodate the variability in unregulated and regulated conditions.

\section{Application of the Mixed-Station Maintenance of Variance Type 1 (MOVE.1) Analysis to Synthesize Peak-Flow Data}

The mixed-station MOVE.1 procedure (Alley and Burns, 1983 ) is based on correlation of concurrent peak-flow records for a target gaging station (a gaging station with incomplete peak-flow records during the base period) and one or more index stations (gaging stations that have peak-flow records for one or more of the missing years of the target station). The MOVE.1 fitting procedure, though analogous to ordinary least squares regression, results in an extended peak-flow record with a variance comparable to that of the unextended peak-flow record of the target station (Cary and Parrett, 1996). The use of multiple potential index stations allows additional important peak-flow events or periods of record to be available for record extension that could not be achieved by using a single index station. Also, the mixed-station MOVE.1 procedure can be applied to cases for which an appropriate index station has a shorter record length than the target station. The mixed-station MOVE.1 procedure synthesizes peak-flow data for individual years of missing record for the target station. Errors in estimated peak flows for individual years might be relatively large with use of the mixed-station procedure.

Results from the mixed-station MOVE.1 procedure were reviewed for consistency among gaging stations on the same large river with emphasis placed on specific key years with unusually high or low peak-flow conditions. In some cases, the initial mixed-station MOVE.1 results indicated inconsistencies among some gaging stations for some of the key years. In these cases, the initial mixed-station MOVE. 1 results for some of the key years were adjusted using drainage-area ratio methods described by Sando, Roy, and others (2016), as documented in table 1-3. For a given gaging station, use of the drainage-area ratio methods accounted for a small amount of the combined recorded and synthesized data (generally less than 3 percent) and probably had only minimal effect on the appropriate maintenance of variance within the dataset. Also, use of the drainage-area ratio methods probably had a minimal effect on the reported standard error of prediction (SEP) of the method. However, because the drainage-area ratio methods were used to synthesize some peak flows, the calculation of the SEP for the mixed-station MOVE.1 results was not always precise and is reported as "estimated" in table 1-3.

Documentation regarding the application of the mixedstation MOVE.1 procedure is presented in table 1-3. For a given target station, table 1-3 includes the index stations, the weighted-average Pearson correlation coefficient, and the SEP for the mixed-station MOVE.1 procedure. The weightedaverage Pearson correlation coefficient was determined by multiplying the number of peak flows synthesized based on an index gaging station times the Pearson correlation coefficient for the index gaging station for each index gaging station. The resultant products then were summed and divided by the total number of synthesized peak flows.

In general, confidence in the mixed-station MOVE.1 results increases with increasing weighted-average Pearson correlation coefficient, and confidence also increases with decreasing SEP. In some cases, however, there are inconsistencies in relations between the weighted-average Pearson correlation coefficients and the SEPs. For some target stations, the weighted-average Pearson correlation coefficient is somewhat low (less than about 0.75 ), but the SEP also is somewhat low (less than about 25 percent). The low weighted-average Pearson correlation coefficient indicates that the index station did not strongly explain the variability of the target station; however, the low SEP indicates that variability in the targetstation recorded peak flows was small and also that variability in the synthesized peak flows using the index station(s) was small. In other cases, for some target stations the weightedaverage Pearson correlation coefficient is high (greater than about 0.85 ), but the SEP also is somewhat high (greater than about 40 percent). The high weighted-average Pearson correlation coefficient indicates that the index station explained most of the variability of the target station; however, the high SEP indicates that variability in the target-station recorded peak flows was large and also that variability in the synthesized peak flows using the index station(s) was large. For the cases with inconsistencies in relations between the weighted-average Pearson correlation coefficients and the SEPs, the mixedstation MOVE.1 results were considered to provide reasonable representation of annual peak flows.

The uncertainties in the mixed-station MOVE. 1 results are difficult to directly quantify; thus, it is important to understand the intended use of the estimated frequencies based on analysis of the combined recorded and synthesized datasets. The estimated frequencies are considered general estimates of frequency relations among gaging stations on the same stream channel that might be expected if the gaging stations had been gaged during the same long-term base period. However, 
because the mixed-station MOVE. 1 procedure involves secondary statistical analysis with accompanying errors, the uncertainty of the frequency estimates is larger than would be obtained by collecting systematic records for the same number of years represented by the base period.

\section{Procedures for Frequency Analysis of the Combined Recorded and Synthesized Peak-Flow Data}

Frequency analyses of the combined recorded and synthesized peak-flow data for the selected gaging stations (table 1-3) were conducted using procedures described in detail by Sando, McCarthy, and Dutton (2016), with documentation provided in table 1-4 in appendix 1 at the back of this report chapter (available at https://doi.org/10.3133/ $\operatorname{sir} 20155019 D)$. A brief overview of the procedures is presented herein.

Frequency analyses generally were conducted using procedures described in Bulletin 17B "Guidelines for Determining Flood Flow Frequency" (U.S. Interagency Advisory Council on Water Data, 1982; hereinafter referred to as Bulletin 17B). Bulletin 17B uses the log-Pearson III probability distribution, which is fit by using the mean, standard deviation, and skew of the logs of the combined recorded and synthesized peak flows for a given gaging station. Procedures described in Bulletin 17B were used as primary guidelines for developing the frequency estimates presented in this report chapter. The computer program PEAKFQ, which was developed by the U.S. Geological Survey (Flynn and others, 2006), was used to run the frequency analyses.

Frequencies for the combined recorded and synthesized datasets initially were analyzed using standard Bulletin 17B procedures for fitting the log-Pearson III distribution. In this report chapter, standard Bulletin 17B procedures are considered to include the use of weighted skew coefficients, the use of the Grubbs-Beck outlier test (Grubbs and Beck, 1972) for identifying low outliers, and, where applicable, the use of historical adjustment procedures. Fits of the preliminary frequency curves with the probability plots of the peak flows were then evaluated. In most cases, fits of the standard Bulletin 17B analyses were determined to be satisfactory.

In other cases, however, the frequency estimates could be improved by using alternative procedures for handling specific characteristics of the peak-flow records for some gaging stations. The specific characteristics of peak-flow records addressed by alternative procedures include (1) regulated peak-flow records, (2) mixed-population peak-flow records, and (3) atypical low-end peak-flow records. Stations for which alternative procedures were applied for any of these reasons are noted in table 1-4. The alternative procedures for handling the specific characteristics are described in Sando, McCarthy, and Dutton (2016).

\section{Adjusted Peak-Flow Frequency Estimates for Selected Streamflow- Gaging Stations in or near Montana}

At-site frequency estimates for 504 selected gaging stations (fig. 1, table 1-1) were adjusted by RRE weighting and mixed-station record-extension procedures. The results of the analyses are presented herein.

\section{Adjusted Peak-Flow Frequency Estimates Determined by Weighting with Regional Regression Equations}

Results of weighting with RREs for the 438 selected gaging stations in or near Montana are presented in table 1-2. For each gaging station, the at-site frequency estimates, RRE frequency estimates, and weighted-average frequency estimates are included in appendix table 1-2.

\section{Considerations for Interpreting Results for Weighting with Regional Regression Equations}

The weighted-average frequencies obtained by weighting with RREs generally are considered to provide improved frequency estimates compared to using only at-site frequencies (Cohn and others, 2012). In some cases, differences among the at-site frequency estimates, the regression-equation frequency estimates, and the weighted-average frequency estimates are substantial. In these cases, thoughtful consideration should be applied when selecting the appropriate frequency estimate. Some factors that might be considered when selecting the appropriate frequency estimate include (1) whether the specific gaging station has peak-flow characteristics that distinguish it from most other stations used in developing the RREs for the hydrologic region; and (2) the length of the peak-flow record and the general climatic characteristics during the period when the peak-flow data were collected. Information on peak-flow temporal trends at long-term gaging stations in or near Montana (Sando, McCarthy, and others, 2016) might aid in assessing the general climatic characteristics during the period when the peak-flow data were collected. For critical structure-design and flood-plain mapping applications, a conservative approach would be to select the higher of the at-site frequency estimate (reported by Sando, McCarthy, and Dutton [2016]) and the weighted-average frequency estimate.

\section{Adjusted Peak-Flow Frequency Estimates Determined by Mixed-Station Record Extension}

Frequency estimates for the combined recorded and synthesized datasets for the 66 selected gaging stations (table 1-3) with incomplete peak-flow records during the base 
periods are presented in table $1-5$ in appendix 1 at the back of this report chapter (available at https://doi.org/10.3133/ sir20155019D). Table 1-5 also includes 27 long-term gaging stations with complete datasets during the base periods that were included to assist in assessing adjusted frequency estimates for other gaging stations located on the 19 large rivers. Thus, frequency estimates are reported for a total of 93 gaging stations in table $1-5$. For some of the 27 long-term gaging stations with complete datasets during the base periods, the entire gaged period of record is longer than the base period. The base period frequency estimates are presented for comparison with other stations on the same large river; however, for these longterm gaging stations, more reliable frequency estimates (based on the entire period of record) are reported in Sando, McCarthy, and Dutton (2016).

\section{Considerations for Interpreting Mixed-Station Record Extension Results}

The uncertainties for the mixed-station record extension results are difficult to directly quantify because the mixed-station record extension procedures involve secondary statistical analysis with accompanying errors. The uncertainties for the resultant frequency estimates are larger than would be obtained by collecting systematic records for the same number of years represented by the base period. However, the mixed-station record extension frequency estimates incorporate data from nearby gaging stations (generally on the same river) and are considered to be more representative of actual streamflow conditions during the base periods than frequency estimates derived from the shorter-term, sometimes sporadic, gaged records. It is important to understand the intended use of the frequency estimates based on analysis of the combined recorded and synthesized datasets. The frequency estimates are considered general estimates of frequency relations among gaging stations on the same stream channel that might be expected if the gaging stations had been gaged during the same long-term base period. Caution should be used when using the frequency estimates for important applications, such as structure design. For critical structure-design applications based on a given gaging station, a conservative approach would be to select the higher of the at-site frequency estimate reported by Sando, McCarthy, and Dutton (2016) and mixedstation record extension frequency estimate.

For some gaging stations on some of the large rivers, the frequency estimates for some AEPs do not always increase in the downstream direction, as might typically be the case for many unregulated natural streams. While decreases in peak flows in a downstream direction are unusual for unregulated rivers, decreases in a downstream direction can be fairly common for regulated rivers and can result from effects of reservoir operations and irrigation diversions. For cases where frequency estimates decreased between an upstream gaging station and the next downstream gaging station, concurrent periods of record for the gaging stations were investigated to verify that the relations between the frequency estimates generally were similar to the relations between the recorded concurrent peak flows.

The mixed-station record extension frequency estimates for Bitterroot River at Bell Crossing near Victor, Montana (gaging station 12350250; map number 680) should be used with caution. The MOVE.1 analysis for this station has a low weighted-average Pearson correlation coefficient (0.56; table 1-3), a high SEP (88.8 percent; table 1-3), and synthesized peak flows account for a large proportion (65 percent; table 1-5) of the combined recorded and synthesized peak-flow data. The hydrology of the Bitterroot River near gaging station 12350250 is especially complex and affected by canal diversions and return flows.

\section{Summary}

The climatic conditions of the specific time period during which peak-flow data were collected at a given streamflowgaging station (hereinafter referred to as gaging station) can substantially affect how well the peak-flow frequency (hereinafter referred to as frequency) estimates represent long-term hydrologic conditions. Differences in the timing of the periods of record can result in substantial inconsistencies in frequency estimates for hydrologically similar gaging stations. Potential for inconsistency increases with decreasing peak-flow record length. The representativeness of the frequency estimates for a short-term gaging station can be adjusted by various methods including weighting the at-site results in association with frequency estimates from regional regression equations (RREs) by using the Weighted Independent Estimates (WIE) program. Also, for gaging stations that cannot be adjusted by using the WIE program because of regulation or drainage areas too large for application of RREs, frequency estimates might be improved by using record extension procedures, including a mixed-station analysis using the maintenance of variance type I (MOVE.1) procedure. The U.S. Geological Survey, in cooperation with the Montana Department of Transportation and the Montana Department of Natural Resources and Conservation, completed a study to provide adjusted frequency estimates for selected gaging stations through water year 2011.

The purpose of Chapter D of this Scientific Investigations Report is to present adjusted frequency estimates for 504 selected gaging stations in or near Montana based on data through water year 2011. Estimates of peak-flow magnitudes for the 66.7-, 50-, 42.9-, 20-, 10-, 4-, 2-, 1-, 0.5-, and 0.2-percent annual exceedance probabilities are reported. These annual exceedance probabilities correspond to the 1.5-, 2-, 2.33-, 5-, 10-, 25-, 50-, 100-, 200-, and 500-year recurrence intervals, respectively.

For gaging stations with characteristics that allow estimation of frequencies using RREs, the at-site frequencies can be adjusted by weighted averaging with the results from the RREs. The at-site frequency estimates for 438 selected gaging 
stations in Montana were adjusted by weighting with results from RREs using the WIE program. The 438 selected gaging stations (1) had periods of record less than or equal to 40 years, (2) represented unregulated or minor regulation conditions, and (3) had drainage areas less than about 2,750 square miles.

The weighted-average frequencies obtained by weighting with RREs generally are considered to provide improved frequency estimates. In some cases, differences among the at-site frequency estimates, the regression-equation frequency estimates, and the weighted-average frequency estimates are substantial. In these cases, thoughtful consideration should be applied when selecting the appropriate frequency estimate. Some factors that might be considered when selecting the appropriate frequency estimate include (1) whether the specific gaging station has peak-flow characteristics that distinguish it from most other stations used in developing the RREs for the hydrologic region; and (2) the length of the peak-flow record and the general climatic characteristics during the period when the peak-flow data were collected. For critical structure-design applications, a conservative approach would be to select the higher of the at-site frequency estimate and the weighted-average frequency estimate.

The mixed-station MOVE.1 procedure generally was applied in cases where three or more gaging stations were located on the same large river, and some of the gaging stations could not be adjusted using the weighted-average method because of regulation or drainage areas too large for application of RREs. The mixed-station MOVE. 1 procedure was applied to 66 selected gaging stations on 19 large rivers.

The general approach for using mixed-station record extension to adjust at-site frequencies involved (1) determining appropriate base periods for the gaging stations on the large rivers, (2) synthesizing peak-flow data for the gaging stations with incomplete peak-flow records during the base periods by using the mixed-station MOVE.1 procedure, and (3) conducting frequency analysis on the combined recorded and synthesized peak-flow data for each gaging station. Frequency estimates for the combined recorded and synthesized datasets for 66 gaging stations with incomplete peak-flow records during the base periods are presented. The uncertainties in the mixed-station record extension results are difficult to quantify; thus, it is important to understand the intended use of the estimated frequencies based on analysis of the combined recorded and synthesized datasets. The estimated frequencies are considered general estimates of frequency relations among gaging stations on the same stream channel that might be expected if the gaging stations had been gaged during the same long-term base period. However, because the mixed-station record extension procedures involve secondary statistical analysis with accompanying errors, the uncertainty of the frequency estimates is larger than would be obtained by collecting systematic records for the same number of years represented by the base period. Caution should be used when using the frequency estimates for important applications, such as structure design. For critical structure-design applications based on a given gaging station, a conservative approach would be to select the higher of the at-site frequency estimate and the mixed-station record extension frequency estimate.

\section{References Cited}

Alley, W.M., and Burns, A.W., 1983, Mixed station extension of monthly streamflow records: Journal of Hydraulic Engineering, American Society of Civil Engineers, v. 109, no. 10, p. 1272-1284. [Also available at http://dx.doi. org/10.1061/(ASCE)0733-9429(1983)109:10(1272).]

Cary, L.E., and Parrett, Charles, 1996, Synthesis of natural flows at selected sites in the upper Missouri River Basin, Montana, 1928-89: U.S. Geological Survey WaterResources Investigations Report 95-4261, 109 p. [Also available at http://pubs.er.usgs.gov/publication/wri954261.]

Cohn, T.A., Berenbrock, Charles, Kiang, J.E., and Mason, R.R., Jr., 2012, Calculating weighted estimates of peak streamflow statistics: U.S. Geological Survey Fact Sheet 2012-3038, 4 p. [Also available at http://pubs.usgs.gov/ fs/2012/3038/.]

Cohn, T.A., Lane, W.L., and Stedinger, J.R., 2001, Confidence intervals for expected moments algorithm flood quantile estimates: Water Resources Research, v. 37, no. 6, p. 1695-1706. [Also available at http://dx.doi. org/10.1029/2001WR900016.]

Flynn, K.M., Kirby, W.H., and Hummel, P.R., 2006, User's manual for PeakFQ, annual flood frequency analysis using Bulletin 17B guidelines: U.S. Geological Survey Techniques and Methods, book 4, chap. B4, 42 p. [Also available at http://pubs.usgs.gov/tm/2006/tm4b4/.]

Grubbs, F.E., and Beck, Glenn, 1972, Extension of sample sizes and percentage points for significance tests of outlying observations: Technometrics, v. 14, no. 4, p. 847-854. [Also available at http://dx.doi.org/10.2307/1267134.]

McCarthy, P.M., Dutton, D.M., Sando, S.K., and Sando, Roy, 2016, Montana StreamStats - A method for retrieving basin and streamflow characteristics in Montana: U.S. Geological Survey Scientific Investigations Report 2015-5019-A, 16 p. [Also available at http://dx.doi.org/10.3133/sir20155019A.]

Sando, Roy, Sando, S.K., McCarthy, P.M., and Dutton, D.M., 2016, Methods for estimating peak-flow frequencies at ungaged sites in Montana based on data through water year 2011: U.S. Geological Survey Scientific Investigations Report 2015-5019-F, 30 p. [Also available at http://dx.doi. org/10.3133/sir20155019F.] 
Sando, S.K., Driscoll, D.G., and Parrett, Charles, 2008, Peak-flow frequency estimates based on data through water year 2001 for selected streamflow-gaging stations in South Dakota: U.S. Geological Survey Scientific Investigations Report 2008-5104, 367 p. [Also available at http://pubs. usgs.gov/sir/2008/5104/.]

Sando, S.K., McCarthy, P.M., and Dutton, D.M., 2016, Peakflow frequency analyses and results based on data through water year 2011 for selected streamflow-gaging stations in or near Montana: U.S. Geological Survey Scientific Investigations Report 2015-5019-C, 27 p. [Also available at http:// dx.doi.org/10.3133/sir20155019C.]

Sando, S.K., McCarthy, P.M., Sando, Roy, and Dutton, D.M., 2016, Temporal trends and stationarity in annual peak flow and peak-flow timing for selected long-term streamflowgaging stations in or near Montana through water year 2011: U.S. Geological Survey Scientific Investigations Report 2015-5019-B, 48 p. [Also available at http://dx.doi. org/10.3133/sir20155019B.]
Tasker, G.D., 1980, Hydrologic regression with weighted least squares: Water Resources Research, v. 16, no. 6, p. 11071113.

Tasker, G.D., and Stedinger, J.R., 1989, An operational GLS model for hydrologic regression: Journal of Hydrology, v. 111, p. 361-375. [Also available at http://dx.doi. org/10.1016/0022-1694(89)90268-0.]

U.S. Geological Survey, 2014, National Water Information System (NWISWeb): U.S. Geological Survey database, accessed November 27, 2014, at http://waterdata.usgs.gov/ nwis/.

U.S. Interagency Advisory Council on Water Data, 1982, Guidelines for determining flood flow frequency: Hydrology Subcommittee, Bulletin 17B, appendixes 1-14, 28 p. 

Appendix 1 


\section{Appendix 1. Information on Selected Streamflow-Gaging Stations, Peak-Flow Frequency Adjustment Methods, And Adjusted Peak-Flow Frequency Estimates}

This appendix presents information on selected streamflow-gaging stations for which at-site peak flow frequencies presented in Sando, McCarthy, and Dutton (2016) were adjusted by various methods (table 1-1). Documentation regarding adjustment methods is presented in table 1-3 for the mixed-station maintenance of variance type I (MOVE.1) record extension procedure and in table 1-4 for the combined recorded and synthesized peak-flow data. Peak-flow frequency estimates for selected streamflow-gaging stations are presented in table 1-2 for those adjusted by weighting with regional regression equations and in table 1-5 for those that were adjusted by mixed-station record extension procedures.

An Excel file containing the tables is available at https://doi.org/10.3133/sir20155019D.

Table 1-1. Information on selected streamflow-gaging stations in or near Montana for which at-site peak-flow frequencies were adjusted.

Table 1-2. Peak-flow frequency estimates for selected streamflow-gaging stations in or near Montana that were adjusted by weighting with regional regression equations.

Table 1-3. Documentation regarding the application of the mixed-station maintenance of variance type I (MOVE.1) record extension procedure for selected streamflow-gaging stations in or near Montana.

Table 1-4. Documentation regarding analytical procedures for peak-flow frequency analyses on combined recorded and synthesized peak-flow data for selected streamflow-gaging stations.

Table 1-5. Peak-flow frequency estimates for selected streamflow-gaging stations in or near Montana that were adjusted by mixedstation record extension.

Publishing support provided by:

Rolla Publishing Service Center

For more information concerning this publication, contact:

Director, Wyoming-Montana Water Science Center

U.S. Geological Survey

3162 Bozeman Ave

Helena, MT 59601

(406) $457-5900$

Or visit the Wyoming-Montana Water Science Center Web site at:

https://wy-mt.water.usgs.gov/ 

